\begin{tabular}{|c|l|}
\hline Title & Comparative study on general properties of alginate lyases from some marine gastropod mollusks \\
\hline Author(s) & $\begin{array}{l}\text { Hata, Mami; Kumagai, Y uya; Rahman, Mohammad Matiur; Chiba, Satoru; Tanaka, Hiroyuki; Inoue, A kira; Ojima, } \\
\text { Taka0 }\end{array}$ \\
\hline Citation & $\begin{array}{l}\text { Fisheries Science, 75(3), 755-763 } \\
\text { https:/doi.org/10.1007/312562-009-0079-z }\end{array}$ \\
\hline Issue Date & 2009-05 \\
\hline Doc URL & http://hdl.handle.net/2115/38478 \\
\hline Rights & The original publication is available at www.springerlink.com \\
\hline Type & article (author version) \\
\hline File Information & 75-3_p755-763.pdf \\
\hline
\end{tabular}

Instructions for use 


\title{
Comparative Study on General Properties of Alginate Lyases from Some Marine Gastropod Mollusks
}

\author{
Running title: Alginate Lyases from Marine Gastropod
}

Mami HATA, ${ }^{1}$ Yuya KUMAGAI, ${ }^{1}$ MOHAmmad Matiur RAHMAN, ${ }^{1}$ SAtoru CHIBA, ${ }^{2}$ HiROYUKI TANAKA, ${ }^{1}$ AKIRA INOUE, ${ }^{1}$ and TAKAO OJIMA ${ }^{1 *}$

${ }^{1}$ Laboratory of Marine Biotechnology and Microbiology, Graduate School of Fisheries Sciences, Hokkaido University, Hakodate, Hokkaido 041-8611, Japan

${ }^{2}$ Central Research Laboratory of Nippon Suisan Kaisha Ltd., Hachioji, Tokyo 192-0906, Japan

*Correspondence author: Tel/Fax: 81-138-40-8800. E-mail: ojima@fish.hokudai.ac.jp 
ABSTRACT: Alginate lyase (EC 4.2.2.3) is an enzyme that splits glycosyl linkages of alginate chain via $\beta$-elimination producing unsaturated oligoalginates. This enzyme is widely distributed in herbivorous marine mollusks, brown algae, and marine and soil bacteria. In the present study, we determined the general properties and partial amino-acid sequences of alginate lyases from three Archeogastropoda, i.e., Haliotis discus hannai, H. iris, and Omphalius rusticus, and one Mesogastropoda, i.e., Littorina brevicula, in order to enrich the information about functional and structural diversity in gastropod alginate lyases. The alginate lyases were extracted from hepatopancreas of these animals and purified by ammonium sulfate fractionation followed by conventional column chromatography. Single alginate lyases with molecular masses of approximately $28 \mathrm{kDa}, 34 \mathrm{kDa}$, and $34 \mathrm{kDa}$ were isolated from H. discus, H. iris, and O. rusticus, respectively. While three alginate lyases with molecular masses of $35 \mathrm{kDa}, 32$ $\mathrm{kDa}$, and $28 \mathrm{kDa}$ were isolated from L. brevicula. These enzymes were identified as poly(M) lyase (EC 4.2.2.3) since they preferably degraded poly(M)-rich substrate. Western blot analysis using an antiserum raised against $H$. discus enzyme suggested that $H$. iris, and $O$. rusticus enzymes shared similar primary/higher order structure with $H$. discus enzyme, but the $L$. brevicula enzymes did not. $H$. discus, $H$. iris, and $O$. rusticus enzymes were classified to polysaccharide-lyase family-14 by the analysis of partial amino-acid sequences, while the $L$. brevicula enzymes were not.

KEY WORDS: alginate lyase, gastropod, mollusks, polysaccharide-lyase family, amino-acid sequence 


\section{INTRODUCTION}

Alginate is an acidic heteropolysaccharide consisting of $\beta$-D-mannuronic acid (M) and $\alpha$-L-guluronic acid $(\mathrm{G})$, which are arranged as homopolymeric poly(M) and poly(G) blocks and heteropolymeric poly(MG) block. ${ }^{1-3}$ Alginate exists as an intercellular structural material of brown algae and a constituent of biofilms of certain bacteria. ${ }^{1-4}$ Since the solution of sodium alginate exhibits high viscosity and the calcium salt forms elastic gel, alginate has been used as a wide range of food and industrial materials. ${ }^{2,5}$ Recently, enzymatically degraded alginate was found to exhibit certain biological activities, e.g., promotion of root growth in higher plants, ${ }^{6-8}$ acceleration of a growth rate of Bifidobacterium sp., ${ }^{9}$ and induction of production of cytotoxic cytokines in human mononuclear cells, ${ }^{10,11}$ suppression of IgE, ${ }^{12}$ and antihypertensive effects. ${ }^{13-14}$ Accordingly, alginate-degrading enzyme i.e., alginate lyase, as well as alginate oligosaccharides is attracting attentions of researchers in the fields of food and pharmaceutical industries.

Alginate lyase degrades alginate by a $\beta$-elimination mechanism to produce alginate oligosaccharides forming a double bond between the C4 and C5 carbons at the non-reducing terminus of the oligosaccharides. ${ }^{2-4}$ This enzyme is distributed over herbivorous marine mollusks, ${ }^{15-23}$ brown algae, ${ }^{24,25}$ marine and soil bacteria, ${ }^{4,26-30}$ and chlorella virus. ${ }^{31}$ As for molluscan enzymes, poly(M) lyase (EC 4.2.2.3) has been isolated from abalone (Haliotis. rufescens, ${ }^{15} \mathrm{H}$. corrugate, ${ }^{15} \mathrm{H}$. tuberculata, ${ }^{20} \mathrm{H}$. discus hannai $^{22,23}$ ), turban shell (Turbo cornutus ${ }^{18}$ ), sea hare (Dolabella auricular ${ }^{16}$ ), and small marine snail (Littorina sp. ${ }^{17}$ ), and the lyase activity has been detected in sea hare (Aplysia depilans and A. californica) ${ }^{19}$ and bivalves (Choromytilus meridionalis, Perna perna, Spisula solidissima). ${ }^{32}$ These molluscan alginate lyases appear to play roles for 
degradation of alginate in their dietary algae and facilitate the assimilation of intracellular nutrients of the algae. In addition, the degradation products of alginate also appeared to be utilized by the mollusks as a carbon source. Namely, it was recently reported that alginate oligosaccharides were incorporated to hepatopancreas of turban shell. ${ }^{33}$ Further, we have noticed that the substantial amounts of alginate oligosaccharides were accumulated in hepatopancreas of abalone satiated with Laminaria sp., and these oligosaccharides were consumed by fasting for a few days (unpublished results). The metabolic pathways of alginate oligosaccharides in mollusks have remained obscure.

Among the molluscan alginate lyases, abalone and turban shell enzymes are the best characterized ones. For example, endolytic and exolytic alginate lyases, HdAly and HdAlex, respectively, have been isolated from digestive fluid of the pacific abalone $H$. discus hannai, ${ }^{22,23}$ while two endolytic enzymes, SP1 and SP1 have been isolated from hepatopancreas of turban shell T. cornutus. ${ }^{18,21}$ Primary structures of HdAly and HdAlex were deduced by the cDNA method, ${ }^{22,23}$ while that of SP2 was determined by the protein method. ${ }^{21}$ These abalone and turban shell enzymes are classified as members of polysaccharide-lyase family-14 (PL-14) among 18 PL families on the basis of hydrophobic cluster analysis of primary structure (http://www.cazy.org/). Compared with abalone and turban shell enzymes, other molluscan alginate lyases have not been so well characterized and no primary structure data is available. Therefore, other than abalone and turban shell enzymes at present we cannot classify the molluscan alginate lyases vastly i.e., which PL families other molluscan alginate lyases belongs to. In order to improve current information about the molluscan alginate lyases, it is important to study many different molluscan enzymes comparatively. 
In the present study, we compared basic properties and partial amino-acid sequences of alginate lyases from $H$. discus hannai, $H$. iris, and Omphalius rusticus (Archeogastropoda), and from L. brevicula (Mesogastropoda), in order to obtain information about the functional and structural diversity of alginate lyases in marine gastropod mollusks.

\section{MATERIALS AND METHODS}

\section{Materials}

The pacific abalone $H$. discus hannai was obtained from a local market in Hakodate, Hokkaido prefecture, Japan. The blackfoot abalone $H$. iris was kindly supplied by Central Research Laboratory of Nippon Suisan Kaisha Ltd. Small marine gastropods, $O$. rusticus and L. brevicula were collected from tidal zone in the shore of Hakodate. Sodium alginate (Macrocystis pyrifera origin) was purchased from Sigma-Aldrich Inc. (St. Louis, MO, USA). Poly(M) block, poly(MG) block, and poly(G) blocks were prepared by the method of Gacesa and Wusteman. ${ }^{34}$ TOYOPEARL CM-650M was purchased from Tosoh Co. (Tokyo, Japan). Other chemicals were from Wako Pure Chemical Industries Ltd. (Osaka, Japan).

\section{Preparation of gastropod alginate lyases}

Alginate lyase from $H$. discus hannai, HdAly, was isolated as reported previously. ${ }^{22}$ Alginate lyases from H. iris, O. rusticus, and L. brevicula, named HiAly, OrAly, and LbAly, respectively, in the present study, were isolated as following methods. HiAly 
was extracted from the minced hepatopancreas (approx. $100 \mathrm{~g}$ ) of $H$. iris with $300 \mathrm{ml}$ of $10 \mathrm{mM}$ sodium phosphate buffer $(\mathrm{pH} 7.0)$ for $30 \mathrm{~min}$. The extract was centrifuged at $10,000 \mathrm{x} \mathrm{g}$ for $10 \mathrm{~min}$, and the supernatant was subjected to ammonium sulfate fractionation. Proteins precipitated between 70 and $90 \%$ saturation of ammonium sulfate was collected by centrifugation and dissolved in and dialyzed against $10 \mathrm{mM}$ sodium phosphate buffer ( $\mathrm{pH}$ 7.0). The dialysate was then subjected to TOYOPEARL CM-650M column $(2.0 \times 20 \mathrm{~cm})$ pre-equilibrated with the same buffer and the proteins adsorbed to the column were eluted with a linear gradient from 0 to $0.3 \mathrm{M} \mathrm{NaCl}$ in 10 $\mathrm{mM}$ sodium phosphate buffer ( $\mathrm{pH} 7.0)$. HiAly showing a single band with $34 \mathrm{kDa}$ on SDS-PAGE was eluted at around $0.25 \mathrm{M} \mathrm{NaCl}$. Protein and activity yields from the initial extract of HiAly were $1.12 \mathrm{mg}$ and $1.24 \%$, respectively. OrAly was extracted from the minced hepatopancreas (approx. $50 \mathrm{~g}$ ) with $150 \mathrm{ml}$ of sodium phosphate buffer (pH 7.0) and subjected to ammonium sulfate fractionation. Proteins precipitated between 60 and 90\% saturation of ammonium sulfate were dialyzed against $10 \mathrm{mM}$ sodium phosphate buffer (pH 7.0) and subjected to TOYOPEARL CM-650M column $(2.0 \times 20 \mathrm{~cm})$ equilibrated with the same buffer. The adsorbed proteins were eluted with a linear gradient from 0 to $0.3 \mathrm{M} \mathrm{NaCl}$ in the same buffer. OrAly was eluted at around $0.12 \mathrm{M} \mathrm{NaCl}$ from the column; however, it contained small amounts of $40-70-\mathrm{kDa}$ proteins. Thus, OrAly was further purified by hydroxyapatite column chromatography. Namely, the OrAly fraction was applied to a hydroxyapatite column $(1.4$ x $22 \mathrm{~cm})$ pre-equilibrated with $10 \mathrm{mM}$ potassium phosphate buffer ( $\mathrm{pH}$ 7.0) and the adsorbed proteins were eluted with a linear gradient from 0.01 to $0.3 \mathrm{M}$ potassium phosphate (pH 7.0). OrAly showing a single band of approximately $34 \mathrm{kDa}$ on SDS-PAGE was eluted at around $0.2 \mathrm{M}$ potassium phosphate buffer $(\mathrm{pH}$ 7.0). Protein and activity yields from 
the initial extract of OrAly were $0.51 \mathrm{mg}$ and $5.4 \%$, respectively. LbAly was extracted from the minced hepatopancreas (approx. $30 \mathrm{~g}$ ) with $10 \mathrm{mM}$ sodium phosphate buffer (pH 7.0) and subjected to ammonium sulfate fractionation. LbAly precipitated between 70 and $100 \%$ saturation of ammonium sulfate was dialyzed against $10 \mathrm{mM}$ sodium phosphate buffer ( $\mathrm{pH}$ 7.0) and then subjected to a TOYOPEARL CM-650M column $(1.6 \times 14 \mathrm{~cm})$ pre-equilibrated with the same buffer. The adsorbed proteins were eluted with a linear gradient of 0 to $0.3 \mathrm{M} \mathrm{NaCl}$. In this chromatography, alginate lyases were eluted at three positions, namely, at around 0.08, 0.1, and 0.16M NaCl. Molecular masses of the enzymes included in the $0.08,0.1$, and $0.16 \mathrm{M} \mathrm{NaCl}$ fractions were estimated as $35 \mathrm{kDa}, 32 \mathrm{kDa}$, and $28 \mathrm{kDa}$, respectively. Thus, we named these enzymes LbAly35, LbAly32, and LbAly28, respectively. These enzymes were further purified by hydroxyapatite column chromatography to remove trace amounts of contaminated proteins similarly to the case of OrAly. Protein and activity yields of LbAly 35, LbAly32, and LbAly28 were $0.22 \mathrm{mg}$ and $1.0 \%, 0.18 \mathrm{mg}$ and $0.8 \%$, and $0.1 \mathrm{mg}$ and 0.5\%, respectively. SDS-PAGE of these purified alginate lyases are shown in Fig. 1.

\section{Assay for lyase activity}

Alginate lyase activity was assayed at $30^{\circ} \mathrm{C}$ in a reaction mixture containing $10 \mathrm{mM}$ sodium phosphate buffer $(\mathrm{pH} \quad 7.0)$ and $0.12 \%(\mathrm{w} / \mathrm{v})$ sodium alginate, poly(M), poly(MG) or poly(G) substrate, and $0.01-0.05 \mathrm{mg} / \mathrm{ml}$ enzyme. Degradation of

substrates was monitored by measuring the absorbance at $235 \mathrm{~nm}$ with a spectrophotometer HITACHI Model U-3010 (Tokyo, Japan) equipped by a thermal controlling apparatus SP-12R (TAITEC, Tokyo, Japan). One unit of alginate lyase was defined as the amount of enzyme that increases Abs235nm to 0.01 for 1 min. Optimal 
temperature of enzyme was determined by measuring the activity at $10-70^{\circ} \mathrm{C}$ in 10 $\mathrm{mM}$ sodium phosphate buffer ( $\mathrm{pH}$ 7.0). Thermal stability of enzyme was assessed by measuring the activity remaining after the heat treatment at $15-55^{\circ} \mathrm{C}$ for $20 \mathrm{~min}$. $\mathrm{pH}$ dependence of the activity was determined in a reaction mixture containing $50 \mathrm{mM}$ sodium phosphate buffer adjusted to $\mathrm{pH} 4.5$ - 10.5. pH stability of enzyme was assessed as follows. The enzyme was dissolved in $50 \mathrm{mM}$ sodium phosphate buffer adjusted to $\mathrm{pH} 3.0-11.0$ and incubated at $30^{\circ} \mathrm{C}$ for $15 \mathrm{~min}$. Then, $0.05 \mathrm{ml}$ of the enzyme solution was added to $0.25 \mathrm{ml}$ of ice-cold $100 \mathrm{mM}$ sodium phosphate buffer $(\mathrm{pH} 7.0)$ and $0.1 \mathrm{ml}$ of the mixture was subjected to activity assay under standard conditions $\left(30^{\circ} \mathrm{C}\right.$ and $\mathrm{pH}$ 7.0) as described above.

\section{SDS-polyacrylamide gel electrophoresis}

SDS-polyacrylamide gel electrophoresis (SDS-PAGE) was carried out with $0.1 \%$ (w/v) SDS-10\% (w/v) polyacrylamide slab gel by the method of Porzio and Pearson. ${ }^{35}$ After the electrophoresis, the gel was stained with $0.2 \%(\mathrm{w} / \mathrm{v})$ Coomassie Brilliant Blue R-250, and the background of the gel was destained with $5 \%(\mathrm{v} / \mathrm{v})$ methanol-7\% (v/v) acetic acid. Protein Marker, Broad Range (New England BioLabs, Ipswich, MA, USA) was used as a molecular mass marker.

\section{Preparation of antiserum against HdAly}

An antiserum to the abalone alginate lyase HdAly was raised as follows. HdAly purified by TOYOPEARL CM-650M column chromatography was subjected to SDS-PAGE using a 2 mm-thick slab gel and briefly stained with Coomassie Brilliant Blue R-250. Gel portion containing HdAly was excised from the gel with a scalpel and homogenized 
with $50 \mathrm{mM}$ sodium phosphate buffer ( $\mathrm{pH}$ 7.5) using glass homogenizer. The homogenate was dialyzed overnight against the same buffer and centrifuged at 10,000 $\mathrm{x}$ g for $10 \mathrm{~min}$. The HdAly in the supernatant was lyophilized and stored at $-20^{\circ} \mathrm{C}$ until use. This procedure was repeated several times to obtain approx. $0.2 \mathrm{mg}$ of the gel-purified HdAly. Then, the HdAly was dissolved in $0.2 \mathrm{ml}$ of $0.12 \mathrm{M} \mathrm{NaCl}-10 \mathrm{mM}$ sodium phosphate buffer (pH 7.0) and emulsified with an equal volume of Freunds' complete adjuvant (Wako Pure Chemical Industries, Ltd.). The emulsion (0.1 ml) was injected to the backside of a male rabbit (New Zealand White) for three times at 2 weeks intervals with the same dosage. After confirmation of antibody production (on day 7 after the last injection), cardiac blood was obtained from the rabbit and solidified at $37^{\circ} \mathrm{C}$ for $1 \mathrm{~h}$ and cooled to $4^{\circ} \mathrm{C}$. The serum was collected by centrifugation at 10,000 $\mathrm{x} g$ for $10 \mathrm{~min}$ and stored in aliquots at $-80^{\circ} \mathrm{C}$ until use.

\section{Western blot analysis}

Western blot analysis was performed according to the method of Towbin et al. ${ }^{36}$ Alginate lyase was subjected to SDS-PAGE, and then transferred to a nitrocellulose membrane (Tosoh Co.) using a Horize-Blott semi-dry blotter (ATTO, Tokyo, Japan) at $120 \mathrm{~mA}$ for $120 \mathrm{~min}$. Rabbit anti-HdAly antiserum generated in the present study was used as the primary antibody and horseradish-peroxidase-conjugated goat anti-rabbit IgG (Sigma-Aldrich) was used as the secondary antibody. The secondary antibody on the blot was detected by color development with $0.6 \%$ (w/v) 4-chloro-1-naphtol and 0.3\% (v/v) hydrogen peroxide in 20\% (v/v) methanol-0.05 M Tris-HCl ( $\mathrm{pH} 7.5)$. MagicMark XP Western Protein Standard (Invitrogen, Carlsbad, CA, USA) was used as a molecular mass marker for the blot. 


\section{Determination of partial amino-acid sequences}

The N-terminal amino-acid sequences of alginate lyases were determined with the samples electrically blotted to a poly(vinylidene difluoride) (PVDF) membrane after SDS-PAGE using a protein sequencer Procise 492 (Applied Biosystems, Foster City, CA, USA). For the analysis of internal amino-acid sequences of the alginate lyase, proteolytic fragments were prepared by the digestion with $1 / 100$ (w/w) of lysylendopeptidase at $37^{\circ} \mathrm{C}$ for $2 \mathrm{~h}$. The fragments were transferred to a PVDF membrane after SDS-PADE and several well separated fragments on the membrane were subjected to the sequencer. When matrix-assisted laser desorption/ionization time-of-flight mass spectrometry (MALDI-TOF MS) was used for the analysis of amino acid sequences, the target band on SDS-PAGE was excised from the gel and subjected to in-gel tryptic digestion with Montage In-Gel Digest Kit (Millipore, Waltham, MA, USA) according to the manufacturer's protocol. Peptide fragments were extracted from the gel with 50\% (v/v) acetonitrile-5\% (v/v) trifluoroacetic acid and desalted with ZipTip (Millipore, Bedford, MA, USA), and then subjected to a MALDI TOF-MS (ABI 4700 proteomics analyzer, Applied Biosystems). The amino-acid sequences of the fragments were determined by MS/MS mode with DeNovo Explorer software (Applied Biosystems). Homology searches of the amino-acid sequences to databases were performed with the FASTA and BLAST programs (http://fasta.ddbj.nig.ac.jp/top-j.html, http://blast.ddbj.nig.ac.jp/top-j.html) provided by DNA Data Bank of Japan.

\section{Protein concentration}

Protein concentration was determined by the Biuret ${ }^{37}$ or Lowry ${ }^{38}$ method using bovine 
serum albumin fraction $\mathrm{V}$ as a standard protein.

\section{RESULTS}

\section{Determination of general properties of the alginate lyases}

Alginate lyases, HdAly, HiAly, and OrAly, isolated from $H$. discus hannai, H. iris, and O. rusticus, showed the molecular masses of $28 \mathrm{kDa}, 34 \mathrm{kDa}$, and $34 \mathrm{kDa}$, respectively (Fig. 1). While, three alginate lyases from $L$. brevicula showed the molecular masses of $35 \mathrm{kDa}, 32 \mathrm{kDa}$ and $28 \mathrm{kDa}$. Accordingly, we named them LbAly35, LbAly32, and LbAly28, respectively. In the present study, we used LbAly35 for the determination of enzyme properties as a representative of Littorina enzymes, since the yield of LbAly35 was the highest. Overall properties of the Littorina enzymes have been confirmed to be similar to each other.

In case of substrate preferences of the enzymes, all alginate lyases tested in the present study preferably degraded poly(M) block (Fig. 2). Specific activities of HdAly, HiAly, OrAly, and LbAly35 toward poly(M) block were 9080, 4620, 2040, and 4320 U/mg, respectively. These alginate lyases also could degrade poly(MG) block but hardly poly $(\mathrm{G})$ block. Accordingly, these enzymes were regarded as poly(M) lyases (EC 4.2.2.3). But slight differences among the enzymes were also demonstrated. Namely, HdAly, HiAly, and OrAly degraded native alginate in a similar rate to poly(MG) block, while, LbAly degraded it at a higher rate than poly (MG) block. Such type of substrate preference of LbAly35 was also shown in LbAly32 and LbAly28 (data not shown). This substrate preference may be one of the characteristic properties of Littorina enzymes. HiAly, OrAly, and LbAly35 were regarded as endolytic alginate lyases like HdAly and 
SP2 as these enzymes rapidly decreased viscosity of alginate substrate in the initial phase of the reaction (data not shown).

Optimal temperature and thermal stability of the alginate lyases were determined (Fig. 3a and b). The optimal temperature for HiAly was the lowest, i.e., at $35^{\circ} \mathrm{C}$, whereas the optimal temperature for both HdAly and OrAly was moderate, i.e. $45^{\circ} \mathrm{C}$. LbAly35 showed the highest optimal temperature at $50^{\circ} \mathrm{C}$. The thermal stability of the enzymes was then assessed by measuring the activity remaining after 20 -min incubation at 15 $55^{\circ} \mathrm{C}$. Temperatures at which activity decreased to $50 \%$ of the original activity for 20 min incubation were 38, 41, 43, and $50^{\circ} \mathrm{C}$ for HiAly, OrAly, HdAly, and LbAly35, respectively (Fig. 3b). This indicated that the thermal stability of LbAly35 was roughly 10 degrees higher than the other enzymes. Then, optimal $\mathrm{pH}$ of the enzymes was determined (Fig. 4a). HiAly, HdAly, and OrAly showed the highest activity at around $\mathrm{pH} 8.0$ - 8.5, while LbAly35 showed at $\mathrm{pH} 7.5$, which is $0.5-1.0 \mathrm{pH}$ unit lower than those of other enzymes. pH stability of the enzymes was assessed by measuring the activity remaining after 15 -min incubation at various pHs and $30^{\circ} \mathrm{C}$. As shown in Fig. 4b, the $\mathrm{pH}$ ranges at which $90 \%$ or more activity of the enzymes remained were at $\mathrm{pH} 6$ - 9 for HdAly, HiAly, and OrAly, while pH 3 - 11 for LbAly35. Thus, LbAly35 showed considerably high stability in a broad $\mathrm{pH}$ range compared with the other molluscan enzymes.

\section{Western-blot analysis with anti-HdAly antiserum}

According to the substrate preference and thermal and pH stabilities, LbAly35 appeared

to possess somewhat different properties from the other molluscan enzymes. The differences in enzyme properties may be in part due to the differences in the primary 
and/or higher order structure of the enzyme. Therefore, we examined occurrence of the structural differences between LbAly35 and other molluscan alginate lyases by Western-blot analysis using rabbit anti-HdAly antiserum. As shown in Fig. 5, the antiserum cross reacted with HiAly and OrAly; however, it showed practically no reactivity to the Littorina enzymes, LbAly35, LbAly 32, and LbAly 28. Accordingly, HiAly and OrAly were considered to share similar primary/higher order structure with HdAly, while LbAly35, LbAly32, and LbAly28 were not.

\section{Determination of partial amino-acid sequences of the alginate lyases}

Western blot analysis indicated that substantial structural differences existed between HdAly and Littorina enzymes (LbAlys). Then, we determined N-terminal amino-acid sequences of LbAlys along with those of HiAly and OrAly, and compared them with the sequences of HdAly and SP2 which belong to PL-14. As shown Fig. 6, N-terminal amino-acid sequences of HiAly and OrAly showed high similarity to those of HdAly and SP2, while those of LbAlys showed similarity less than 15\%. FASTA and BLASTA searches indicated that the $\mathrm{N}$-terminal amino-acid sequences of LbAlys showed practically no similarity to any sequences currently deposited to the protein and nucleic-acid databases. In order to obtain information about the overall characteristics in primary structure, we digested the HdAly, HiAly, OrAly, and LbAly35 with trypsin and subjected to MALDI-TOF-MS. As shown in Fig 7 a-d, several peptide peaks with similar molecular masses were detected among the MS of HdAly, HiAly, and OrAly. Then, we focused on several fragments with the molecular masses around $800-1,500$ Da and subjected to the analysis of primary structure with MS/MS mode. Accordingly, the amino-acid sequences of two fragments from HiAly with molecular masses of 
1340.74 Da and 1443.72 Da were determined as IVFTIDHLNIR and RGEWQNIAQSVR, respectively. These sequences showed high similarity to the sequences of 1331.75-Da and 1073.57-Da fragments from HdAly, i.e., LVFTIDQLNIR and WQNIAQSVK, respectively. These sequences correspond to the regions of 214 224 residues and 187 - 205 residues in the primary structure of HdAly determined previously. $^{22}$ On the other hand, amino-acid sequences of 1340.73-Da and 1101.56-Da fragments from OrAly were determined as WQNIAQSVR and IVFTIDHLNIR, respectively. These were also similar to the sequences of HdAly, LVFTIDQLNIR and WQNIAQSVK, respectively. On the other hand, there appeared no fragment showing similar molecular mass to the HdAly fragments in MS of LbAly35, especially around a mass range of $800-1,500 \mathrm{Da}$. Thus, we selected some smaller fragments of LbAly35 and determined their amino-acid sequences by MS/MS mode. However, no fragment showing appreciable similarity to the primary structure of HdAly was found. For example, amino-acid sequences, TISSGIFR and IPGIWGGAMK, determined with 880.43-Da and 1029.53-Da fragments from LbAly35, respectively, showed no similarity to any regions in the primary structure of HdAly. These sequences from LbAly35 also showed no similarity to any sequences currently deposited in the databases. Although the above analyses were limited to partial amino-acid sequences, we consider that HiAly and OrAly are classified to PL-14 as in case with HdAly and SP2, while not the Littorina enzymes.

\section{DISCUSSION}

\section{General properties of the molluscan alginate lyases}


In the present study, we isolated alginate lyases, HdAly, HiAly, and OrAly, from $H$. discus hannai, H. iris, and O. rusticus, respectively, while three alginate lyases, LbAly35, LbAly32, and LbAly28, from L. brevicula. The occurrence of heterogeneous alginate lyases in Littorina sp. was previously reported, and an enzyme with the molecular mass of $40 \mathrm{kDa}$, named alginate lyase VI, was isolated. ${ }^{17}$ LbAly35 may correspond to the alginate lyase IV because of the similar molecular mass. HdAly, HiAly, OrAly, and LbAly35 preferably degraded poly(M) block but not poly(G) block, thus they were regarded as poly(M) lyases (EC 4.2.2.3). Slight differences between LbAly35 and the other enzymes were shown in the degradation rate for native alginate substrate. Namely, LbAly35 degraded native alginate in a higher rate than poly(MG) block. Although the reason for this characteristic action of LbAly35 to alginate is obscure, this may reflect the differences in the splitting site of alginate by Littorina and Haliotis enzymes. Namely, it has been reported that the Littorina alginate lyase IV split M/M but Haliotis enzyme split M/G, M/M, or G/M (“/” represents the splitting site). ${ }^{17}$ Precise analysis for the substrate specificity using oligosaccharides with known structures is essential to clarify the reason for the difference in substrate preference between Haliotis and Littorina enzymes. Different properties of LbAly35 from the other enzymes were also seen in $\mathrm{pH}$ dependences and temperature and $\mathrm{pH}$ stabilities. For example, optimal $\mathrm{pH}$ of LbAly35 was at $\mathrm{pH} 7.4$, which was $0.5-1.0 \mathrm{pH}$ unit more acidic side than those of HdAly, HiAly, and OrAly. The temperature that caused a half inactivation during 30-min incubation was observed at around $50^{\circ} \mathrm{C}$ in LbAly35, while those were at around $40^{\circ} \mathrm{C}$ in other enzymes. Further, LbAly35 was stable in a wider $\mathrm{pH}$ range compared with the other enzymes, i.e., LbAly35 showed practically no decrease in activity upon incubation at $\mathrm{pH} 3-11$ for 15 min, while other enzymes greatly 
inactivated at $\mathrm{pH}$ below 5 and above 9. These results strongly suggest that LbAly35 is structurally more stable than the other molluscan enzymes. The high stability of LbAly35 might be related to the molecular adaptation of enzyme to habitat temperature of L. brevicula. Namely, L. brevicula inhabits in a tidal zone where the habitat temperature greatly changes, e.g., from 15 to $40^{\circ} \mathrm{C}$ in a day due to the exposure to direct sunshine as well as the ebb and flow of the tide. On the other hand, Haliotis and Omphalius inhabit under the tidal zone where habitat temperature appeared to be modestly changes around $10-15^{\circ} \mathrm{C}$.

\section{Structural diversity in the alginate lyases}

According to Western-blot analysis HiAly and OrAly were found to show high cross reactivity with rabbit anti-HdAly antiserum. On the other hand, LbAly35, LbAly32, and LbAly28 showed practically no cross-reactivity with the antiserum. These led us to consider that HiAly and OrAly share similar primary/higher order structure to HdAly, while LbAly35, LbAly32, and LbAly28 do not. Then, we determined partial amino-acid sequences of these enzymes and confirmed that HiAly and OrAly possess the homologous sequences with those of HdAly and SP2 that belong to PL-14. These results suggested that HiAly and OrAly were also classified to PL-14. It is noteworthy that partial amino-acid sequences of LbAly35 showed practically no similarity to the sequence of HdAly and to any sequences deposited in the protein and nucleic acid databases. This may indicate that the Littorina alginate lyase is classified to a novel polysaccharide-lyase family whose primary structure has not determined yet. The diversity of primary structures between Littorina and Haliotis enzymes may be relating to the phylogenetic divergence in gastropod. Namely, Haliotis, Turbo, and Omphalius 
belong to Archeogastropoda, while Littorina belongs to Mesogastropoda. This also suggests that the molluscan PL-14 enzyme is specifically distributed in Archeogastropoda among gastropods. In order to explore the phylogenetic relationship and process of molecular evolution for molluscan alginate lyases, it seems necessary to compare genetic structures and primary structures of alginate lyases from different orders. Analysis of complete amino-acid sequence of LbAly35 is now underway.

\section{ACKNOWLEDGMENTS}

This study was supported by a Grant-in-Aid for Scientific Research (No. 10380117) and the $21^{\text {st }}$ century COE Program “Marine Bio-Manipulation Frontier for Food Production" of the Ministry of Education, Culture, Sports, Science and Technology of Japan.

\section{REFERENCES}

1. Haug A, Larsen B, Smidsrød O. Studies on the sequence of uronic acid residues in alginic acid. Acta. Chem. Scand. 1967; 21: 691-704.

2. Gacesa P. Alginates. Carbohydr. Polym. 1988; 8: 161-182.

3. Gacesa P. Enzymatic degradation of alginates. Int. J. Biochem. 1992; 24: 545-552.

4. Wong TY, Preston LA, Schiller NL. Alginate lyase: Review of major sources and enzyme characteristics, structure-function analysis, biological roles, and applications. Annu. Rev. Microbiol. 2000; 54: 289-340.

5. Draget KI, Smidsrod O, Skjak-Braek G. Alginates from algae. In: Beats SD, Vandamme EJ, Steinbuchel A (eds.) Biopolymer 2002; vol. 6, Polysaccharides II. WILEY-VCH Germany, pp. 215-244.

6. Tomoda Y, Umemura K, Adachi T. Promotion of barley root elongation under 
7. Sutherland IW. Polysaccharide lyases. FEMS Microbiol. Rev. 1995; 16: 323-347.

8. Xu X, Iwamoto Y, Kitamura Y, Oda T, Muramatsu T. Root growth-promoting activity of unsaturated oligomeric uronates from alginate on carrot and rice plants. Biosci. Biotechnol. Biochem. 2003; 67: 2022-2025.

9. Akiyama H, Endo T, Nakakita R, Murata K, Yonemoto Y, Okayama K. Effect of depolymerized alginates on the growth of Bifidobacteria. Biosci. Biotechnol. Biochem. 1992; 56: 355-356.

10. Natsume, M., Kamo, Y., Hirayama, M., and Adachi, T. Isolation and characterization of alginate-derived oligosaccharides with root growth-promoting activities. Carbohydr. Res. 1994; 258: 187-197.

11. Iwamoto Y, Xu X, Tamura T, Oda T, Muramatsu T. Enzymatically depolymerized alginate oligomers that cause cytotoxic cytokine production in human mononuclear cells. Biosci. Biotechnol. Biochem. 2003; 67: 258-263.

12. Yoshida T, Hirano A, Wada H, Takahashi K, Hattori M. Alginic acid oligosaccharide suppresses Th2 development and IgE production by inducing IL-12 production. Int. Arch. Allergy Immunol. 2004; 133: 239-247.

13. Tsuchida T, Chaki T, Ogawa H. Effect of sodium alginate oligosaccharide on human blood pressure. Med. Cons. New-Remed. (in Japanese). 2001; 38: 555-560.

14. Chaki T, Nishimoto S, Hiura N, Satou R, Tou Y, Kakinuma S. Effect of a powdered drink containing sodium alginate oligosaccharide on blood pressure in mild hypertensive and high normal blood pressure subjects. J. Nutr. Food. (in Japanese). 2002; 5: 41-54. 
15. Nakada HI, Sweeny PC. Alginic Acid Degradation by Eliminases from Abalone Hepatopancreas. J. Biol. Chem. 1967; 242: 845-851.

16. Nishizawa K, Fujibayashi S, Kashiwabara Y. Alginate lyases in the hepatopancreas of a marine mollusk, Dolabella auricular Solander. J. Biochem. (Tokyo). 1968; 64: 25-37.

17. Elyakova LA, Favarov VV. Isolation and certain properties of alginate lyase VI from the mollusk Littorina sp. Biochim. Biophys. Acta. 1974; 358: 341-354.

18. Muramatsu T, Hirose S, Katayose M. Isolation and properties of alginate lyase from the mid-gut gland of wreath shell Turbo cornutus. Agric. Biol. Chem. 1977; 41: 1939-1946.

19. Boyen C, Kloareg B, Polne-Fuller M, Gibor A. Preparation of alginate lyases from marine molluscs for protoplast isolation in brown algae. Phycol. 1990; 29: 173-181.

20. Heyraud A, Colin-Morel P, Girond S, Richard C, Kloareg B. HPLC analysis of saturated or unsaturated oligoguluronates and oligomannuronates. Application to the determination of the action pattern of Haliotis tuberculata alginate lyase. Carbohydr. Res. 1996; 291: 115-126.

21. Muramatsu T, Komori K, Sakurai N, Yamada K, Awasaki Y, Fukuda K, Oda T. Primary structure of mannuronate lyases SP1 and SP2 from Turbo cornutus and involvement of the hydrophobic C-terminal residues in the protein stability. $J$. Protein Chem. 1996; 15: 709-719.

22. Shimizu E, Ojima T, Nishita K. cDNA cloning of an alginate lyase from abalone, Haliotis discus hannai. Carbohydr. Res. 2003; 338: 2841-2852.

23. Suzuki H, Suzuki K, Inoue A, Ojima T. A novel oligoalginate lyase from abalone, Haliotis discus hannai, that releases disaccharide from alginate polymer in an 
24. Madgwick J, Haug A, Larsen B. Alginate lyase in the brown alga Laminaria digitata (Huds.) Lamour. Acta. Chem. Scand. 1973; 27: 711-712.

25. Watanabe T, Nishizawa K. Enzymatic studies on alginate lyase from Undaria pinnatifida in relation to texture-softening prevention by ash-treatment (Haiboshi). Bull. Jap. Soc. Sci. Fish. 1982; 48: 243-249.

26. Murata K, Inose T, Hisano T, Abe S, Yonemoto Y, Yamashita T, Takagi M, Sakaguchi K, Kumura A, Imanaka T. Bacterial alginate lyase: enzymology, genetics and application. J. Ferment. Bioeng. 1993; 76: 427-437.

27. Sawabe T, Ohtsuka M, Ezura Y. Novel alginate lyases from marine bacterium Alteromonas sp. strain H-4. Carbohydr. Res. 1997; 28: 69-76.

28. Sugimura II, Sawabe T, Ezura Y. Cloning and sequence analysis of Vibrio halioticoli genes encoding three types of polyguluronate lyase. Mar. Biotechnol. 2000; 2: 65-73.

29. Iwamoto Y, Araki R, Iriyama K, Oda T, Fukuda H, Hayashida S, Muramatsu T. Purification and characterization of bifunctional alginate lyase from Alteromonas sp. strain no. 272 and its action on saturated oligomeric substrates. Biosci. Biotechnol. Biochem. 2001; 65: 133-142.

30. Zhang Z, Yu G., Guan H, Zhao X, Du Y, Jiang X. Preparation and structural elucidation of alginate oligosaccharides degraded by alginate lyase from Vibrio sp. 510. Carbhydr. Res. 2004; 339: 1475-1481.

31. Suda K, Tanji Y, Hori K, Unno H. Evidence for a novel Chlorella virus-encoded alginate lyase. FEMS Microbiol. Lett. 1996; 180: 45-53.

32. Seiderer LJ, Newell RC, Cook PA. Quantitative significance of style enzymes from 
33. Chaki T, Kakimi H, Shibata A, Baba T. Detection of alginate oligosaccharides from mollusks. Biosci. Biotechnol. Biochem. 2006; 70: 2793-2796.

34. Gasesa P, Wusteman FS. Plate assay for simultaneous detection of alginate lyases and determination of substrate specificity. Appl. Environ. Microbiol. 1990; 56: 2265-2267.

35. Porzio MA, Pearson AM. Improved resolution of myofibrillar proteins with sodium dodecyl sulfate-polyacrylamide gel electrophoresis. Biochem. Biophys. Acta. 1977; 490: 27-34.

36. Towbin H, Staehelim T, Gordon J. Electrophoretic transfer of proteins from polyacrylamide gels to nitrocellulose sheets: procedure and some applications. Proc. Natl. Acad. Sci. U.S.A. 1979; 76: 4350-4354.

37. Gornall AG, Bardawill CJ, David MM. Determination of serum proteins by means of the biuret reaction. J. Biol. Chem. 1949; 177: 751-766.

38. Lowry OH, Rosebrough NJ, Farr AL, Randall RJ. Protein measurement with the Folin phenol reagent. J. Biol. Chem. 1951; 193: 265-275. 
Figure captions

Fig. 1 SDS-PAGE for the alginate lyases.

Mk, molecular mass markers. HdAly, $H$. discus hannai enzyme; HiAly, $H$. iris enzyme; OrAly, O. rusticus enzyme; LbAly35, LbAly32 and LbAly 28, L. brevicula enzymes.

Fig. 2 Substrate preference of the alginate lyases. Activities of HdAly (a), HiAly (b), OrAly (c) and LbAly35 (d) were measured with the sodium alginate $(\bigcirc)$, M-block $(\mathbf{O})$, MG-block $(\triangle)$ or G-block $(\boldsymbol{\Delta})$ in a concentration of $0.12 \%(w / v)$. Alginate lyase activity was determined by monitoring the increase in absorbance at $235 \mathrm{~nm}$ due to the degradation of alginate via $\beta$-elimination.

Fig. 3 Temperature dependence and thermal stability of the alginate lyases. (a) Activity was measured at various temperatures in a reaction mixture containing $0.12 \%$ (w/v) sodium alginate, $10 \mathrm{mM}$ sodium phosphate buffer ( $\mathrm{pH} 7.0$ ), and $1 \mathrm{U} / \mathrm{ml}$ enzyme. (b) Enzyme was incubated in $10 \mathrm{mM}$ sodium phosphate buffer ( $\mathrm{pH} 7.0)$ at indicated temperatures for $20 \mathrm{~min}$ and then remaining activity was assayed at $30^{\circ} \mathrm{C}$ in the same mixture. $\bigcirc$, HdAly; $\bigcirc$, HiAly; $\triangle$, OrAly; and $\boldsymbol{\Delta}$, LbAly35.

Fig. $4 \mathrm{pH}$ dependence and $\mathrm{pH}$ stability of the alginate lyases. (a) Activity was measured at $30^{\circ} \mathrm{C}$ in a reaction mixture containing $10 \mathrm{mM}$ sodium phosphate buffer adjusted to various pHs. (b) Enzyme was incubated at $30^{\circ} \mathrm{C}$ at various pHs for $15 \mathrm{~min}$ and the remaining activity was measured at $30^{\circ} \mathrm{C}$ and $\mathrm{pH}$ 7.0. $\bigcirc$, HdAly; $\mathrm{O}$, HiAly; $\triangle$, OrAly; and $\boldsymbol{\Delta}$, LbAly35. 
Fig. 5 Western blot analysis for the alginate lyases. The same samples as in Fig 1 were used for SDS-PAGE followed by the Western blot analysis. Anti-HdAly antiserum and horseradish-peroxidase-conjugated goat anti-rabbit IgG were used as the primary and the secondary antibody, respectively. MagicMark XP Western Protein Standard was used for the molecular mass markers (Mk).

Fig. 6 Comparison of N-terminal amino-acid sequences of the alginate lyases. The N-terminal amino acid sequences of HiAly, OrAly and LbAlys were aligned with those of $\mathrm{HdAly}^{22}$ and $\mathrm{SP} 2^{21}$. Id.(\%) indicates the sequence identity with HdAly. Both HiAly and OrAly showed 90.5\% and 85\% identity with those of HdAly and SP2, respectively. While the sequences of LbAly35, LbAly32 and LbAly28 showed the identity less than $15 \%$ with the sequences of HdAly and SP2.

Fig. 7 Mass spectrometry for tryptic fragments of the alginate lyases. Mass spectrograms for the tryptic fragments of HdAly, HiAly, OrAly, and LbAly35 are shown in figures (a), (b), (c) and (d), respectively. Molecular masses and amino-acid sequences of the peak fragments labeled by arrows are shown on right sides of the arrows. Identical amino-acid residues among HdAly, HiAly, and OrAly fragments are underlined. Numbers indicated by superscript on the HdAly fragments in (a) correspond to the residue numbers in the complete primary structure of HdAly ${ }^{22}$. 
Fig. 1

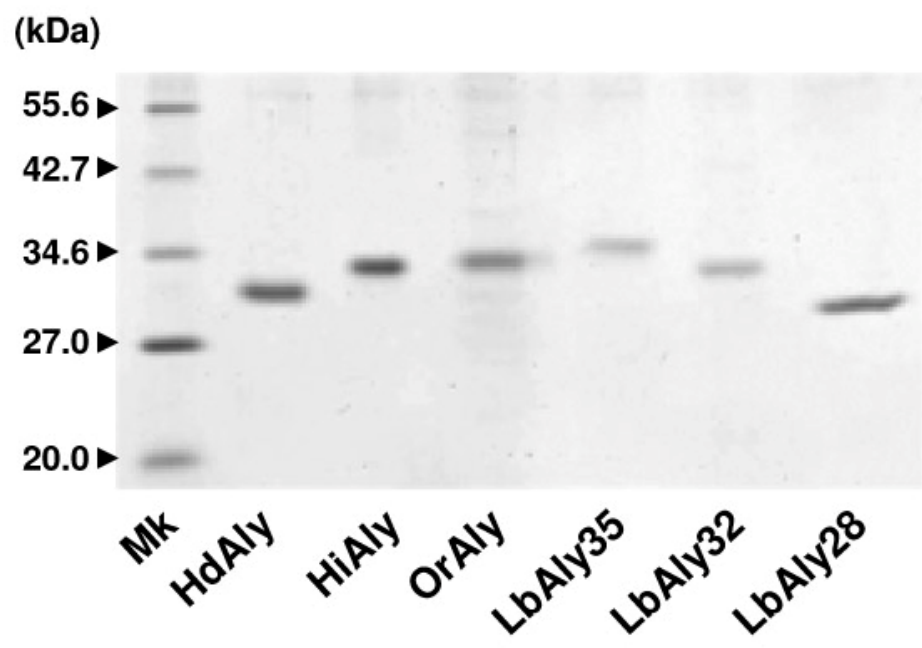


Fig. 2 a - d

(a)

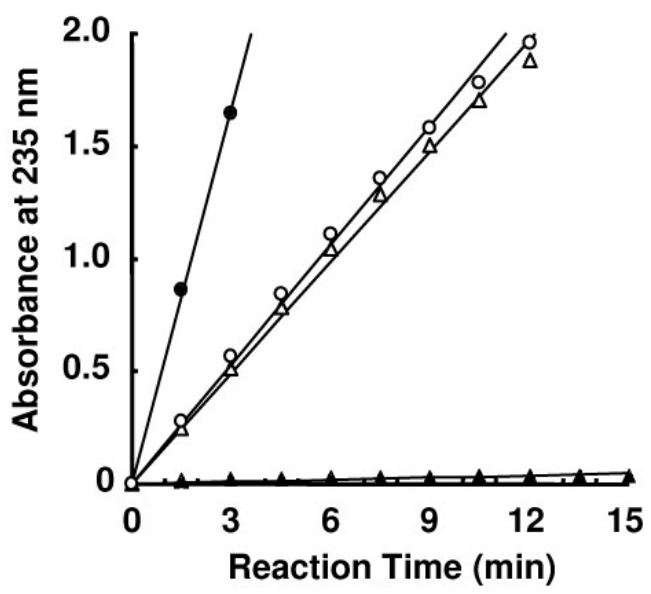

(c)

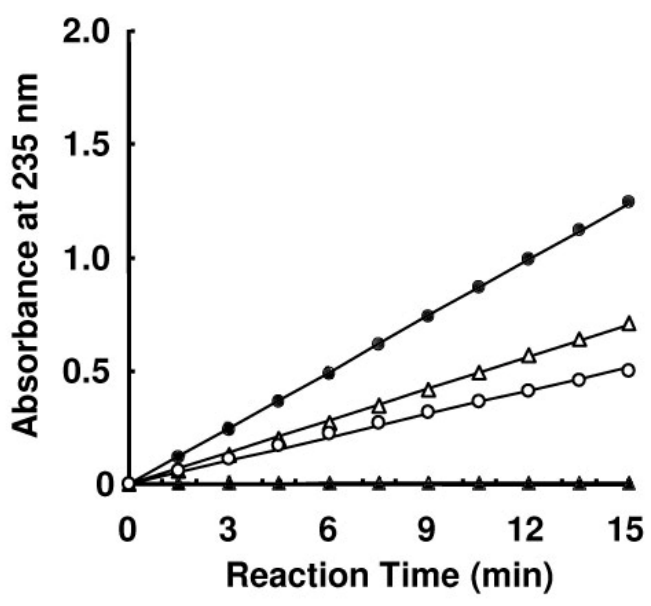

(b)

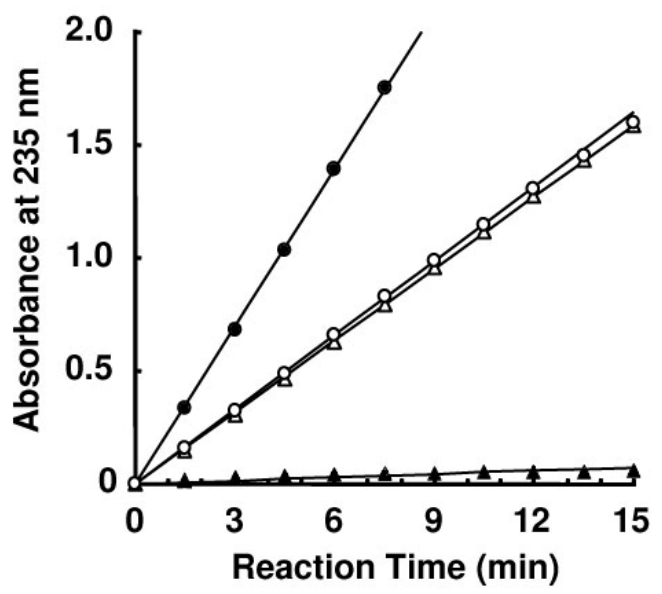

(d)

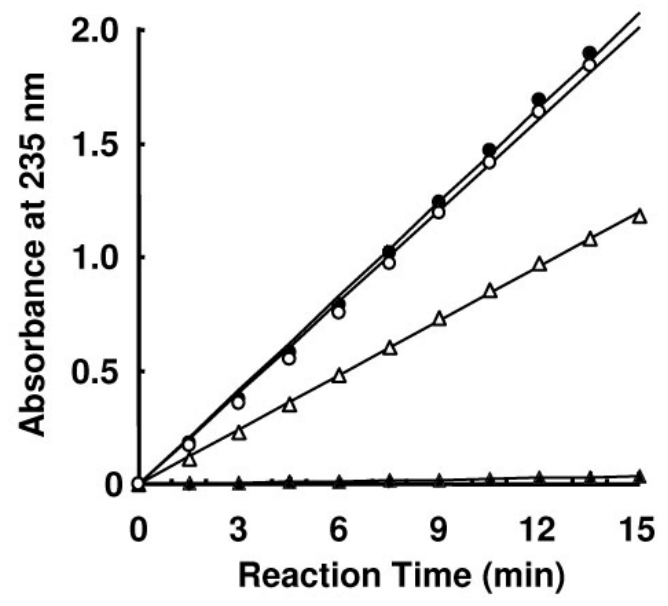


Fig. 3 a $\&$ b

(a)

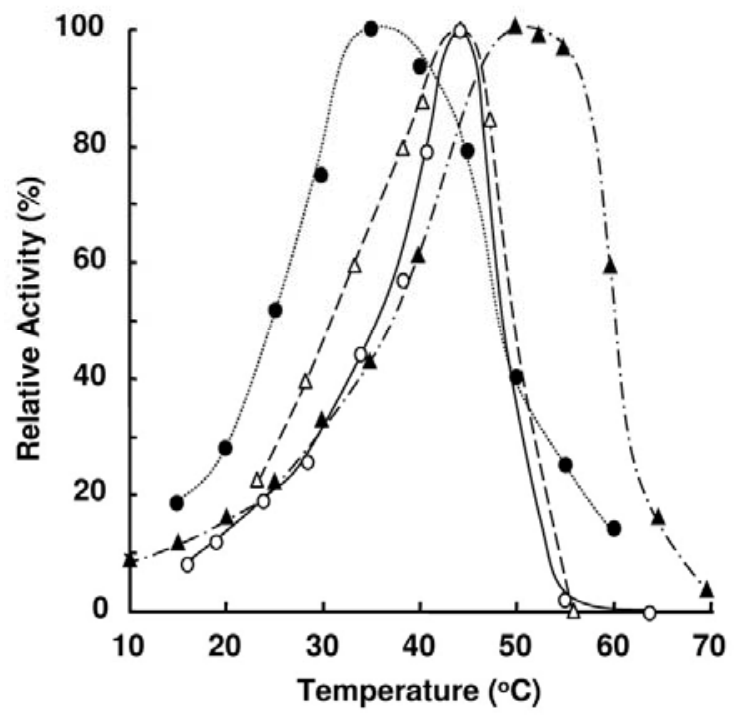

(b)

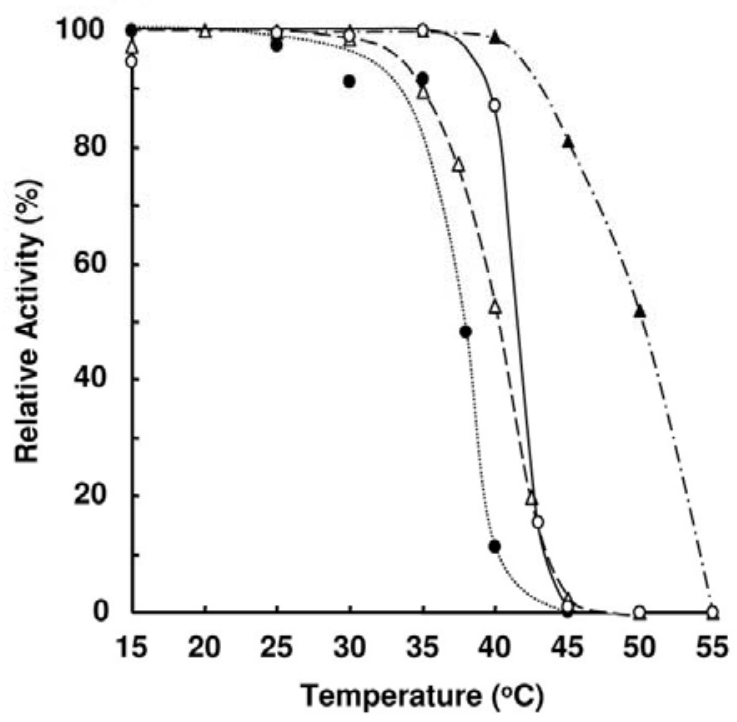


Fig. 4 a \& b

(a)

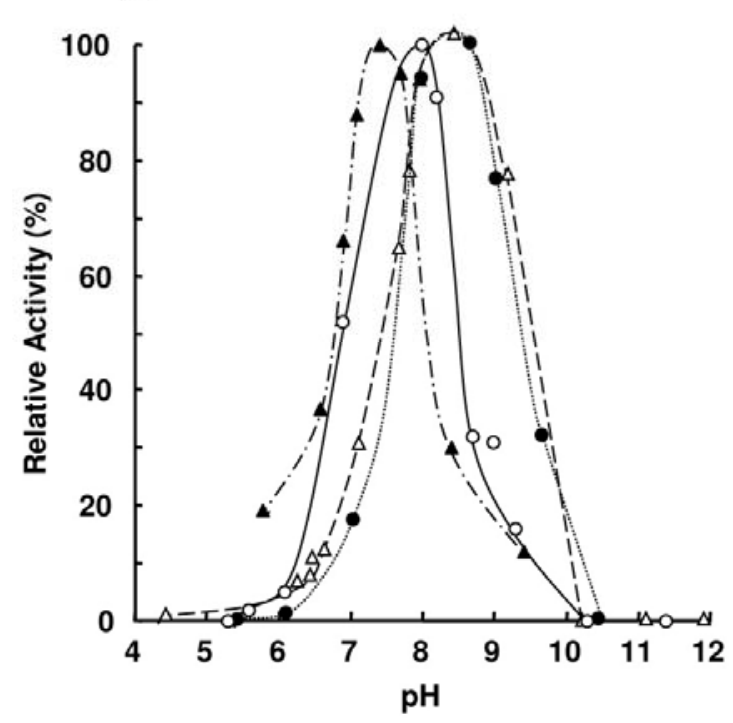

(b)

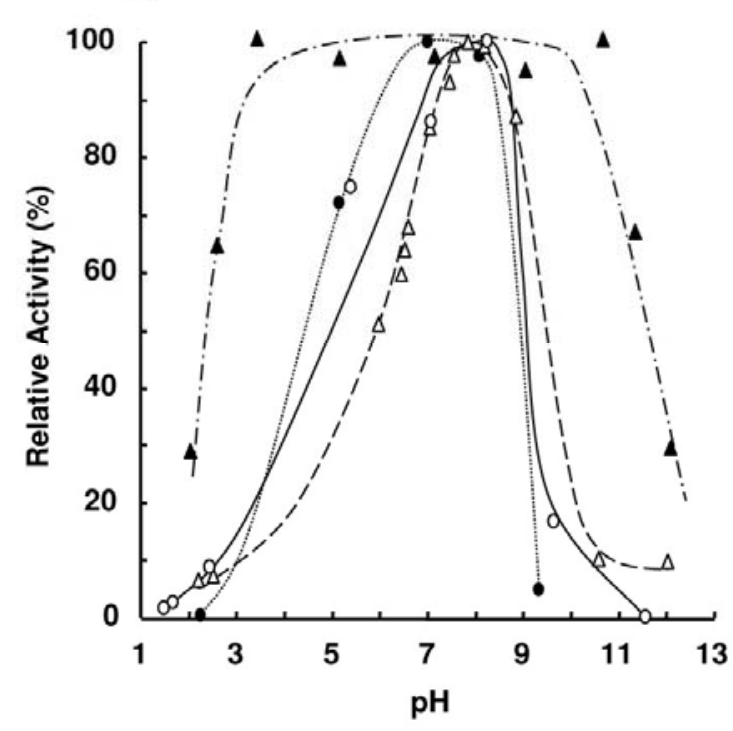


Fig. 5

(kDa)

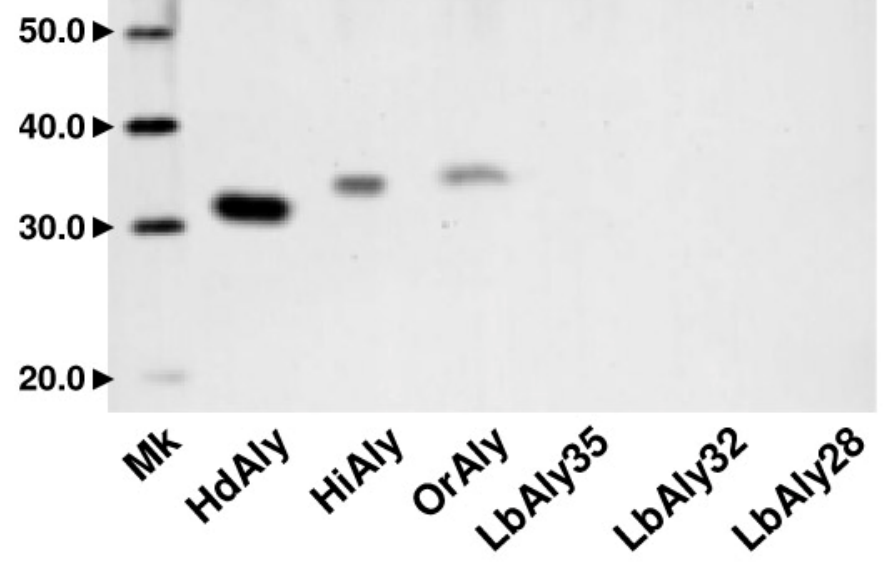


Fig. 6

Id. (\%)

HdAly 18 AVLWTHKEFD PANYRNGMHA LTSNDYDHGS 47

$\begin{array}{llllll}\text { SP2 } & 1 & \text { TLLWTHKEFD PNNYRDGMHA ITSNDYDHGS } & 21 & 85.0\end{array}$

$\begin{array}{llllll}\text { HiAly } & 1 & \text { ?VLWVHKEFD PKNYRNGMHA L } & 21 & 90.5\end{array}$

$\begin{array}{llllll}\text { OrAly } 1 & \text { ?VLWTHKEFD PKNYRNGMHA I } & 21 & 90.5\end{array}$

LbAly35 1 ASGTELFRHT TFTDGSISEA I $\quad 21 \quad 14.3$

LbAly32 1 ASGTELFRHT TFTDGSISEA I $\quad 21 \quad 14.3$

$\begin{array}{lllll}\text { LbAly28 } 1 \text { ASG-ELWRHT TFHSGS } & 15 & 6.7\end{array}$ 
Fig. 7 a - d
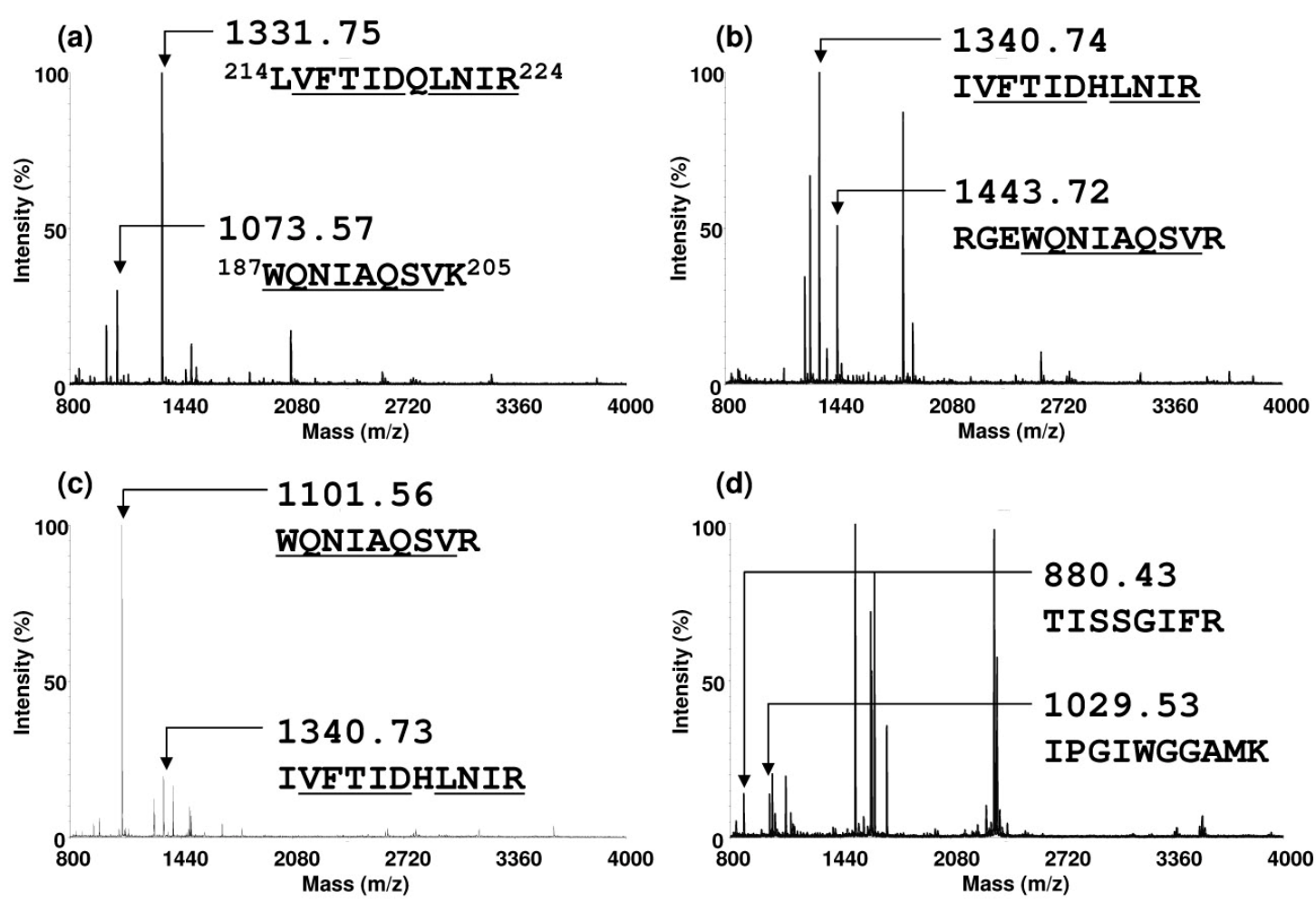

(d)

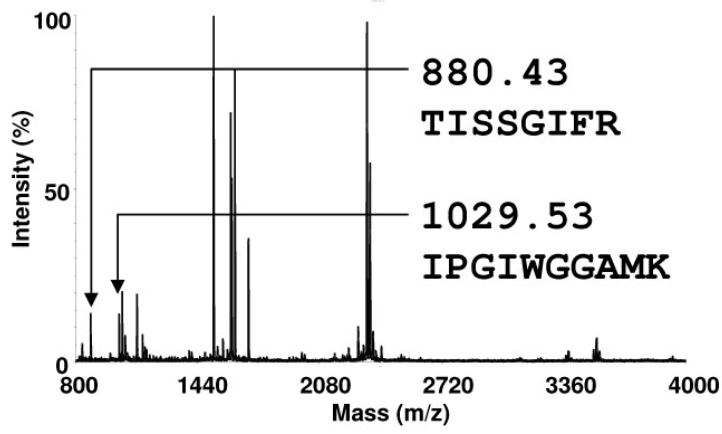

